\title{
Italian minister faces short spell, hot seat
}

Rome. Giorgio Salvini, a particle physicist from the University of Rome, was last week appointed minister for universities and research in Italy's interim government. $\mathrm{He}$ is the fifth research minister since Antonio Ruberti left office after the general elections in spring 1992.

Like his immediate predecessors, Salvini may well be in office for only a matter of months. This is unlikely to be long enough to get to grips with the many problems faced by Italian science, particularly the lack of medium-and long-term planning of research.

Salvini's selection by the new prime minister, the banker Lamberti Dini, came as a surprise to Italian scientists. $\mathrm{He}$ is a respected scientist with many years of experience in research management but, at 74 , he is rather old for such a difficult office.

Salvini set up the national laboratory for particle physics research at Frascati in the 1950 s, and was president of the National Institute for Nuclear Physics (INFN) in the late $1960 \mathrm{~s}$. He also led the Italian research group that participated in Carlo Rubbia's UA1 experiment at the European Laboratory for Particle Physics (CERN), which led to the discovery of two fundamental particles, the $\mathrm{Z}$ and $\mathrm{W}$ bosons.

Since 1990, Salvini has been president of Accademia nazionale dei lincei, the Italian academy of sciences. He now takes over a ministry demoralized by nearly three years of uncertainty. Staff at the ministry look back nostalgically to the era of Ruberti, whose achievements included the introduction of a degree of autonomy into the overcentralized university system, various new research programmes, and the establishment of the Italian Space Agency (ASI).

This momentum has since been lost. Ruberti was succeeded by Sandro Fontana, who held office for 11 months until the government collapsed. He was replaced by Luigi Berlinguer, whose tenure was extremely brief, even by Italian standards: it was a matter of only hours before his PDS party (former communists) resigned from the government.

Umberto Colombo, previously head of the National Agency for New Technology, Energy and the Environment (ENEA), was then appointed minister in the interim government, headed largely by 'technocrats' rather than professional politicians, that took office up to last summer's elections.

During his year of office he sketched out a number of reforms, defining broad priorities for Italian research and proposing a steady increase in research funding from 1.6 to 2.0 per cent of gross national product, and mechanisms for increasing the efficiency with which research money is spent.

These included the introduction of conventional refereeing systems into the $\mathrm{Na}$ tional Research Council (CNR), widely criti- cized for distributing its funds in small packets to keep everyone happy. But Colombo did not have time to see many of his proposals become reality, hoping instead that they would be endorsed by the next elected government. (He is also being tipped as a possible eventual successor to Salvini).

When Stefano Podestá, a member of Forza Italia, was appointed as research minister in Silvio Berlusconi's government last May, he appeared ready to take Colombo's proposals further. But as the government encountered growing difficulties, his actions - and the motives lying behind them - seemed to many to become confused.

Although Italy's economy could not support an immediate increase in general research funds as proposed by Colombo, Podestá's clumsy attempt to cut by a fifth the 1995 budget of ENEA, a body he regarded as inefficient, failed when parliament cut his proposals by 50 per cent.

His bill to change the system by which professors in Italy are selected has been heavily criticized in parliament, in particular for its suggestion that associate professors who have been in post for 12 years could be automatically promoted to full professor on the simple approval of an internal university committee.
Two attempts last autumn to rush through legislation to restructure the financially troubled Italian space agency ASI, and to concentrate control in the hands of a single administrator, were defeated on the grounds that parliament did not consider the issue sufficiently urgent to warrant emergency legislation (see Nature 372, 719; 1994).

Podestá also made himself unpopular among scientists by a decision to include a majority of orthodox Roman Catholics on the national bioethics committee. This led to the resignation of leading members of the committee (see Nature 373, 97; 1995).

Podestá's failures are widely seen as partly a consequence of a refusal to discuss his plans either with experts in the fields concerned or with his fellow politicians, many of whom are also academics. The lack of cross-party support for many of his proposals could have been predicted, while his successor will now inherit more immediate problems than he will have time to deal with.

One result is that hopes for a strong longterm national research policy may once again have to be shelved. "We are used to putting long-term planning aside", says a spokesman from the ministry for universities and research. "But in reality it is dangerous for Italy's future."

Alison Abbott
London. The Royal Society for the Protection of Birds (RSPB) is collaborating with the British police in using DNA fingerprinting to help prevent the theft of eggs from the nests of protected birds of prey in the United Kingdom.

The technique is being used in court cases to reveal whether the offspring of registered captive birds of prey are in fact related to their claimed parents, or have been stolen from nests in the wild and passed off as birds bred in captivity. One result has been a sudden fall in the number of such birds claimed to have been bred in captivity.

A case was due to be heard by Havering magistrates this week (but has now been adjourned until March), in which charges against two breeders will be backed by the demonstration that, of more than $\mathbf{3 0}$ peregrine falcons they claim to have bred, over 20 have been shown by DNA fingerprinting to be unrelated to the 'parents'.

The prosecution - the seventh of its kind - has been brought by the Metropolitan Police, with the help of the RSPB. According to Guy Shorrock, investigations officer for the RSPB, a number of unscrupulous breeders mix eggs from captive birds with those stolen from nests in the wild.

\section{IMAGE UNAVAILABLE FOR COPYRIGHT REASONS}

Wary predator: a falcon in the wild.

Shorrock says that the acceptance by the courts of DNA fingerprinting, which has replaced the need to catch egg thieves in the act, is making potential thieves think twice. "Genetic fingerprinting is a very powerful forensic tool and the sudden decline in captive breeding figures [for peregrine falcons and goshawks] is because it is acting as a deterrent."

The success of the technique has led the RSPB and others to demand the setting up of DNA profile databases of all rare captive birds, to help prevent theft, smuggling and nest robbing. A working group appointed by the government to review the enforcement of wildlife controls is considering whether to recommend genetic registration systems in a report it is due to present in July. Maggie Verrall 